PART 3 



\title{
The Alternative of the Commons, New Politics and Cities
}

\author{
Alexandros Kioupkiolis
}

In the years between 2011 and 2012 history appeared to be "born again" (Badiou 2012) through the Arab Spring, the15-M movement in Spain, the 'squares movement' in Greece and the global Occupy movement. Seven years later, a bleak picture dominates in Europe and across the world as a whole. The global hegemony of neoliberalism remains firmly in place, while reactionary, xenophobic, right-wing politics is on the rise. The scenes of democratic uprisings, mass mobilization, collective empowerment, glimpses of real, egalitarian democracy, and popular aspirations to progressive political change in countries such as Spain and Greece seem to have been consigned to the distant past. ${ }^{90}$

At the time of writing, the financial crises are no longer as acute as they were back in 2011, and a normalization of crisis has taken hold in many countries, with Spain and Greece being the most prominent examples. But the looming ecological catastrophe, the popular disaffection with elitist politics, the devastating consequences of neoliberalism in terms of social justice, equality and meaningful democracy remain our historical horizon. More than ever, it is time

${ }^{90}$ This chapter is part of a project that has received funding from the European Research Council (ERC) under the Horizon 2020 research and innovation programme (grant agreement 724692).

How to cite this book chapter:

Kioupkiolis, A. 2020. The Alternative of the Commons, New Politics and Cities. In Lekakis, S. (ed.) Cultural Heritage in the Realm of the Commons: Conversations on the Case of Greece. Pp. 229-252. London: Ubiquity Press. DOI: https://doi .org/10.5334/bcj.m. License: CC-BY 
to act. But it is also time to take a step back, to re-think and refigure our strategies of egalitarian social change.

In tune with many activists and champions of the commons across the world, the present argument holds that contemporary theories and practices of the commons outline a horizon of historical change which is already in motion, in fits and starts. At the dawn of the new millennium, from the Bolivian Andes (the water wars in Cochabamba, 1999-2000) to the U.S. (e.g. the Creative Commons licences established in 2001) to Southern Europe (e.g. the Italian city regulations for urban participation and self-management) the commons have arisen as a socio-political, economic and cultural paradigm that provides an alternative to both neoliberal capitalism and defunct socialism, social democracy and revolutionary communism.

The commons are not only about co-producing, co-managing and sharing collective resources within a certain community. Numerous social movements, city governments, advocates and political thinkers have made the case in recent years that this is an emergent new historical paradigm, a new mode of production, a new culture, a deeply democratic and ecological politics which can offer a guide, a material foundation and a rallying point for historical change beyond capitalist hegemony and statist socialism or communism. Crucially, in the contemporary European context, a commons-based politics could counter the rise of the nationalist populist right by advancing a progressive way of dealing with social dislocation and alienation, thus restoring solidarity, social trust, collective ties and common welfare. At the same time, alternative commons harbour a radical egalitarian and emancipatory ideal, a visionary pragmatism and an emphasis on massive, bottom-up participation which hold the promise -but only the promise - of overcoming the political frailty, the hierarchical centralism around personal leaders, and the impoverished programmatic imagination of leftist populist parties and governments in Europe, from Podemos to Syriza and Mélanchon.

The following discussion will outline the new paradigm and will introduce certain political propositions on the commons as a counter-hegemonic project. It will then indicate how they lack an adequate political strategy of transition, broad-based mobilization and counter-hegemonic struggle, which could effectively further social transformation in contemporary Europe and the world, transcending the limitations of left-leaning populist parties and governments. In an attempt to start plotting such a strategy, we will draw on the 2011 cycle of democratic mobilizations in Southern Europe and the latest pro-commons politics in Spanish and, mainly, Italian cities. The aim is to explore how powerful counter-hegemonic praxis could be pursued in ways which renew Gramsci's (and Laclau's) hegemonic politics in the direction of alternative commons -horizontal self-government, equality, sustainability, plurality, openness and sharing - and can reshuffle the decks of power.

In the study of commons-oriented politics in the Italian context, we will dwell on the artistic and political community of 'l'Asilo' in Naples, which followed in 
the footsteps of the famous occupation of Teatro Valle in Rome, in 2011, the first of its kind in recent years which explicitly identified itself with the new commons. Among others, the two cases initiated novel, commons-based, practices of governing cultural heritage 'resources'. In effect, they have both striven to act as an alternative to both private and public modes of governance in this field, valuing, revitalizing and 'commoning' cultural heritage. They broke with the conception of cultural heritage as a 'resource' managed bureaucratically or run by private corporations for private benefit.

Both the conceptualization of the commons and, mainly, the fieldwork underpinning theory took place within the context of an ERC-funded project, 'Heteropolitics' (2017-2020); ${ }^{11}$ This project set out to re-think contemporary democratic change from the bottom through the lenses of contemporary commons and radical political theory, from Laclau \& Mouffe to Hardt \& Negri, among others. The present chapter condenses some of the main themes and preliminary conclusions of this research into actual alternative politics which gestures towards an emancipatory and egalitarian direction. The research agenda fostered a close interaction between political theory and reflection, on the one hand, and engagement with praxis on the ground, through ethnographic fieldwork conducted by three post-doctoral researchers in Greece, Spain and Italy (Dr Antonio Vesco was in charge of the fieldwork in Italy).

The guiding intuition behind this composite methodology was that in order to re-think historical transformation in our times, contemporary political theory, attending to the lessons of the $20^{\text {th }}$ century, should engage closely with present-day collective thought so as to learn from ongoing experiments, social creativity, innovation and actual processes of social change on the ground. If the commons are collective goods and processes which are managed autonomously by communities according to egalitarian principles of self-government for the common benefit, commons-oriented thought should likewise unfold as a common endeavour in which all participants are equal co-producers. Crucially, reflection tending to the commons should proceed as a critical interaction with and elucidation of actual initiatives and communities which build the commons of our times. The principles of collective self-direction and emancipation on a footing of equality cannot be dictated from outside and above, otherwise they would suffer the pains of self-contradiction.

From a standpoint situated in present-day Greece, an immersion in the new urban commons in the Italian context assumes particular significance. The two countries share a socio-economic and political crisis, considerable cultural heritage and a huge stock of abandoned historic buildings which are listed for preservation but are barely maintained by state authorities or private capital. The Italian case charts new paths in civic politics and the governance of cultural heritage and social infrastructure more broadly, which could inspire similar initiatives in other places, including Greece.

${ }^{91}$ See heteropolitics.net. Last access 20 November 2019. 


\section{The commons as an alternative world}

The 'commons' or 'common-pool resources' (Ostrom 1990: 30, 90) or 'commons-based peer production' (Benkler \& Nissenbaum 2006: 395) comprise goods and resources that are collectively used and produced. Access to them is provided on equal terms, which may range from totally open access to universal exclusion from consumption, with many possibilities in-between. The common good is collectively administered in egalitarian and participatory ways by the communities that manufacture or own it. Sharing is a fundamental process which lies at the heart of the commons (Walljasper 2010: xix).

There are many different classes of common goods, from natural commonpool resources (fishing grounds, irrigation canals etc.; Ostrom 1990: 30) to common productive assets, such as workers' co-operatives, and digital goods, such as open source software and Wikipedia (Benkler \& Nissenbaum 2006; Dyer-Witheford 2010). Their common baseline, however, is that they involve shared resources which are managed, produced and distributed through collective participation in ways which contest the logic of both private-corporate and state-public property (Ostrom 1990: 1-30, 90; Benkler \& Nissenbaum 2006: 394-396; Dyer-Witheford 2010; Hardt \& Negri 2012: 6, 69-80, 95). Equally important is the fact that existing 'commons' are all threatened by the predatory, privatizing greed of corporate forces and the top-down, monopolistic authority of state powers (Walljasper 2010: xix; Caffentzis 2013; Bollier 2008).

Furthermore, it is now widely held that all commons in their diversity tend to display a tripartite structure. Most definitions render commons as an artifice which consists of three main parts: (a) common resources/goods, (b) institutions (i.e. commoning practices) and (c) the communities (called commoners) who are implicated in the production and reproduction of commons (Dellenbaugh et al. 2015: 13; see also Bollier \& Helfrich 2015: 3).

Finally, it is currently a topos of critical thought on the commons that the commons are not primarily resources or goods, but practices of commoning, that is, of actively forging and reproducing communities of collaboration and action around different dimensions of social life and the environment. Commoners improvise and amend these rules on an ongoing basis, in ways that respond to particular socio-ecological situations and historical contexts. As a result, there is "an incredible range of commoning across time, geography, resource domains and cultural tradition" (Bollier \& Helfrich 2015: 7), which defies any simple formulas and predetermined taxonomies.

But how could dispersed practices and communities around a heteroclite diversity of commons add up to a world-changing process and force? Some enthusiastic champions of the digital commons have asserted that this is already happening. Other, more politically minded thinkers, such as Hardt and Negri, and Dardot and Laval, have laid out political conceptions of the commons which could foster a global shift. In all these cases, however, the shallowness of strategic political thought is glaring. 
To begin with, since the dawn of the new millennium, with the spread of new digital technologies and the Internet, a large body of thought and action has veered attention away from the 'commons of nature' to the 'immaterial' commons of culture, information and digital networks (Benkler 2006; Bollier 2008, 2016; Bauwens 2005, 2009, 2011). Technological change has given rise to new modes of production and collaboration, which enact novel patterns of association and self-governance. These new modes not only reinvent and expand the commons as a culture of co-creation and social sharing outside their traditional bounds of fisheries, forests and grazing grounds, they also represent new schemes of community and collective self-governance beyond the closely knit, stable and homogeneous communities of face-to-face interaction (Benkler 2006: 117-120; Bollier 2008: 2-4; Bauwens 2005). Spanning diverse fields, from software development to online encyclopaedias (Wikipedia) and social media platforms, the new digital environment enables the proliferation of decentralized communities. These combine individual freedom with autonomous social collaboration, holding the promise of more democratic participation, openness, freedom, diversity, creativity and co-production without the hierarchies of the state and the market (Benkler 2006: 2; Bollier 2008: 1-20, 117; Bauwens 2005).

'Digital commoners' argue, in effect, that the networked information commons immensely expand the commons model beyond its traditional, smallscale natural location in forests, land, irrigation channels and fishing grounds. Digital commons remake in their image a wild diversity of social fields, from music to business, law, education and science, refashioning them after the logic of the open, plural, creative and participatory commons (Benkler 2006: 2-3; Benkler \& Nissenbaum 2006; Bollier 2008: 14-18; Bauwens 2005) and disseminating the values and the practices of the commons: sharing, free collaboration for mutual benefit, egalitarian self-organization, openness (Bauwens 2005). According to Bollier (2008: 190), this amounts to a 'Great Value Shift' which has brought about a crucial transformation in subjectivity by propagating, among other ideas and values, a deeply different conception of wealth as commons. As far back as 2005, Bauwens envisioned a new form of society, 'based on the centrality of the commons, and within a reformed state and market' (Bauwens 2005).

Prominent advocates of the digital commons, such as Bollier (2008). Benkler $(2006)$ and Bauwens $(2005,2014)$ concur in a techno-legal and economic fix when they anticipate transitions in the direction of the commons. Despite allusions to 'Common-ist' movements, we are left in the dark as to how these will gather a critical mass, how they will overhaul the 'neoliberal dominance' and how they will reform the state and the market (Bauwens 2005; see also Bauwens 2014: 28). Technology, economic practices, and the law, including Creative Commons Licences, are the main entries. The guiding idea of this movement is to change society, not by fighting the system, but by designing a new model which makes the existing model obsolete (Bollier 2008: 294). 
Historical transformation would be mostly incremental and immanent, arising from within actual social relations and productivity (Bollier 2008: 305-310). "Superior working models - running code and a healthy commons - will trump polemics and exhortation. Ideological activists and political professionals are likely to scoff at this scenario" (Bollier 2008: 305). Society will not be re-ordered, then, by taking political power but through a long process of technologically induced development which advances new social logics of production (Bauwens 2009).

In recent years, an awareness that the techno-economic and legal path runs up against overpowering obstacles has been significantly growing among the peer commons school (see e.g. Bauwens \& Kostakis 2014). Hence, they place an increasing emphasis on the 'partner state,' on social and political movements and on assembling commons counter-power by crafting parallel institutions, such as the 'Chambers of Commons'. Still, the techno-economic and legal steps are always accorded pride of place in both analysis and practice, and the political comes second (Bauwens et al. 2019). They acknowledge that this approach to social renewal "is based solely on the structural changes that take place within the political economy. An integrated strategy needs to also take particular notice on the relevant cultural and subjective changes that vary in every different context" (Bauwens et al. 2019: 55-70).

In effect, an 'integrated strategy' that takes on board political dynamics would need to deploy a full-fledged politics of hegemony, which precisely diffuses cultural and subjective transformations, but is also bent on organizing sociopolitical struggle and on welding together wide, transversal alliances. Work on the regulatory and institutional framework that could push forward the commons is not enough if we lack the agents and the political practices which could reconstruct state structures and economic policies in order to put in place such a framework in the face of bureaucratic resistances and elite opposition.

In the peer commons current, one can also currently discern a heightened consciousness of the fact that political power struggles would be required in order to turn the actual 'market state' into a 'partner state' that tends to common interests and is internally "commonified" (Bauwens et al. 2019: 52-53). Majoritarian social movements of a global reach and new, parallel institutions of the commons should be enlisted and bolstered in this enterprise. But how is it possible to overcome social fragmentation and widespread disaffection in order to band together such movements at a time when economic and political crises push the majority of citizens towards xenophobic and conservative politics across the world? Who could bring them around to a 'common' political perspective, construct a historic bloc for the commons and orchestrate a political transition towards a true 'partner state'? And how could this be achieved? It is this paramount political question that remains unaddressed and cries out for proper political reflection on the level of strategy, agency and organization. 


\section{Counter-hegemonic politics}

Herein lies the political importance of a Gramscian argument for the commons in our times. The principle of the common could rearrange prevalent institutions and structures only if social renewal on the ground - new communities of the commons, new, open and collective technologies of production, and so on - is embedded in a larger political movement contesting hegemony: in a historical bloc (Hoare \& Nowell Smith 1971: 137, 168, 366, 376-377). A fullyfledged hegemonic politics of revolutionary change à la Gramsci is anchored in a broad-based historical bloc which knits together a multiplicity of social resistances and political struggles; economic projects and productive activities that tend to social needs; and the making of a new collective identity, a common political program, values and critical ideas. All these elements are organized through the cohesive force of a committed political alliance.

To put together such a popular front, political actors need to weave organic bonds with large social sectors in their everyday lives, seeking popular outreach and conducting a sustained 'war of position' in civil society and the state, in a way which bridges micro - and macro-politics. Political activity dwells on the micro-level of everyday social activities and groups, engaging directly with social relations and subjectivities so that they transform into a new collective identity, culture and political orientation. At the same time, a common political platform connects the multiplicity of micro-political processes, draws up a coherent and comprehensive political plan adapted to an entire social formation, and wrestles with macro-structures and institutions of the state, the economy, culture and so on.

However, to harness a Gramscian strategy of hegemony for commons-oriented reform today, core elements of Gramscis thought should be problematized, beginning with his centralizing Party and moving on to working class politics. Class inequalities have skyrocketed in our epoch of neoliberal hegemony. Global wealth is amassed world-wide in the hands of a super-rich minority. Middle classes are being increasingly impoverished in many western countries. And the global expelled population - the poor, workers, the unemployed, precarious people, dwellers of shanty towns - who live at or below subsistence level is in the billions. Nonetheless, the 'working class' does not constitute today a unified, massive category which can yield the basis for majoritiarian political identities and mobilization (see Crouch 2004; Dyer-Witherford 2015; Standing 2011). Social differentiation and fragmentation, the pervasiveness of (neo-) liberal individualist values, the decline of industrial labour in developed countries, the growth of precarious labour and the service sector are some of the factors which account for the actual failure of working people across the globe to become politically interpellated as 'working class', to coalesce and to hit back as 'workers' in a single country or internationally. Moreover, the politics of democratic commons needs to devise new patterns of effective political organization 
which break with the centralized, hierarchical and homogenizing party, and are now in tune with the horizontalist, pluralist and egalitarian animus of the commons.

It is worth noting, also, that in a Gramscian strategy the state remains a central site of the struggle, but a protracted 'war of position' in civil society is the effective anchor of historical change against any state-centred politics that aspires to topple neoliberal hegemony and transform society from the top. One of the main challenges today is to work out political structures and agencies that conduct struggles and reconstruct society on all levels in an alliance that prevents top-down direction and the autonomization of parties and leaderships in the political system.

Laclau and Mouffe's relaunch of hegemonic politics in 1985 addresses key predicaments of transformative commons today: how to rally a popular will for antagonistic commons and how to catalyse an expansive convergence of social forces which will overturn the dominance of neoliberal capital and will extend equal freedom around the commons, under circumstances of social fragmentation and complexity, which do not cohere around any simple and given antagonism. Crucially, their reconstruction of hegemony is largely attuned to the spirit of alternative commons, rooted as it is in the "open, unsutured character of the social", "plurality and indeterminacy", the dispersion of power, the autonomy of social movements, the diversity of political spaces and antagonisms (Laclau \& Mouffe 1985: 192, 152). They rid hegemony of Marxist determinism, the determining force of the economic base and class. Their accent on social contingency brings to the fore the always present possibility of historical change against TINA. In doing away with any historical assurances, e.g. technological innovation and networks as the trigger of social transformation, they force us to think politically and to seriously ponder how to organize political action, so as to attain the desired transformations.

Articulation, discourse, plurality and antagonism become the pillars of a postMarxist idea of hegemony. Hegemony is primarily a process of articulation which operates in a contingent terrain and strives to piece together an organized system of relations out of disaggregated elements and differences by way of instituting nodal points (Laclau \& Mouffe 1985: 134-135). Hegemony consists, then, in a particular type of political relation and activity whereby a social force moves outside itself to connect itself with other conflicts through "chains of equivalence" in order to aggregate a collective will. Social actors aspiring to hegemony go beyond their narrow identities and assume broader organizational functions in a community, building coalitions and imputing wider meanings to social practices or resistances (Laclau \& Mouffe 1985: 134-135, 141).

Furthermore, beyond specific demands or negative protests, a winning hegemonic strategy installs nodal points from which a process of different, positive reconstruction of social structures can be set in motion. An effective alter-politics of social transformation thrives on the capacity of subordinated groups to positively direct and renovate a broad range of social spheres. A 
hegemonic strategy for the "construction of a new order" must also conjoin an understanding of existing structural limitations -on the level of the state, the economy etc. - with a utopian vision for another social order (Laclau \& Mouffe 1985: 184, 189, 190).

However, Laclau and Mouffe's hegemonic politics could be reclaimed for a political strategy of alternative commons only if it were released from certain biases of their thought which clash head-on with the horizontalist, pluralist, open and autonomous logic of the commons. Laclau affirmed the vertical distribution of power within the hegemonic alliance, populist homogenization and the need for individual leadership in a counter-hegemonic (see Laclau 2000b: 303; Laclau 2005: 100). However, the distribution of power among the constituents of a radical democratic front can tend towards horizontality rather than towards vertical direction from one particular group at the helm. Unity could be pursued in ways that nurture diversity and pluralism both inside and outside itself. Decision-making and the construction of a collective will could be a participatory and collective process rather than an affair of individual representatives.

\section{Another hegemony for the commons}

Recent democratic activism, such as the 2011 square movements and the 'municipalist' politics from 2015 onwards, provide important insights which can help to re-imagine counter-hegemonic politics around a commons vision.

Unity, the formation of a collective identity, the concentration of force, and leadership make up the backbone of hegemonic politics (Hoare \& Nowell Smith 1971: 152-3, 181-2, 418; Laclau 2000a: 207-212; Laclau 2000b: 301-303). In recent years, egalitarian movements have also made such hegemonic interventions in order to alter the balance of forces. The Occupy Wall Street and the Spanish 15-M movement (or 'Indignados') converged around common ends, practices and signifiers (such as 'the 99\%' and 'the people'). They centralized the co-ordination of action in certain 'hubs' (such as Puerta del Sol in Madrid). They sought to reach out to broader sectors of the population affected by neoliberal governance, and they strove to initiate processes of deeper democratic transformation. They voiced aspirations to radical socio-political change (e.g. 'real democracy'), and they confronted dominant structures of power with vast collections of human bodies and networks.

These civic politics combined 'hegemony' with horizontalism. The 'square movements' of 2011 took aim at the institutionalized separation of political leaders from the people and the sovereign rule of representatives. They set out, instead, to open up the political representation and leadership to ordinary citizens. The very choice of public squares and streets to set up popular assemblies highlights the desire for publicity, transparency and free accessibility of political power to all (Nez 2013). Moreover, in order to preclude the monopolization 
of authority by any individual or group, the assemblies of 2011-2012 enforced binding mandates and alternation in the functions of spokespersons, moderators and special working-groups. Institutional devices such as lot, rotation, limited tenure, increased accountability and the casual alternation of participants in collective assemblies work against the consolidation of lasting divides between rulers and ruled, experts and lay people.

Moreover, diversity and openness became themselves the principle of unity in collective mobilizations such as Occupy Wall Street. Open pluralism has been persistently pursued through a multiplicity of norms, practices and organizational choices. The construction of open spaces of convergence for collective deliberation and coordination stands out among them (Nez 2013). Openness and plurality are further nurtured by a certain political culture which dismisses dogmatic ideologies and strict programmatic definitions in order to appeal to all citizens in their diversity (Harcourt 2011). This culture nurtures tolerance, inclusion, critical respect for differences, civility, generosity, a relaxed atmosphere of debate, and an affective politics of care and love among diverse people who struggle in common despite their differences (Dixon 2014).

The network form, which is widespread among democratic action today, is also crucial. Distributed networks enable a loose coordination among different groups and individuals which need not subordinate their distinct identities to an overarching collective identity or a hegemonic agent, yet they are nested in the same web of communication and act in concert. New organizations, such as the Plataforma de Afectados por la Hipoteca in Spain, illustrate how a more coherent organising core can tie up with a loose group of diverse agents who participate in different degrees, constituting an open 'network system' that allows for plurality and resists strong centralization and fixed hierarchies (Nunes 2014; Tormey 2015).

Finally, pragmatism facilitates modes of convergence and common identity which sustain diversity and openness. A heterogeneous assemblage of agents and practices can more easily cohere around practical objectives rather than around group identities and definite programs or ideologies. Collective action can thereby avoid the fragmentation of 'identity politics.' Acceptance of empirical 'messiness' and hybridity, a flexible approach oriented to concrete problemsolving, an open mind and a reluctance to take universal, dogmatic positions compose a pragmatic outlook which can depolarize strategic choices, supporting broad pluralist assemblages in the interests of the many.

\section{Cities as incubators of counter-hegemonic change}

Massive civic mobilizations, which sought to refigure counter-hegemonic politics along these lines in the years of crisis have failed, however, to reshuffle the decks of power and to rein in, at least, the neoliberal onslaught of austerity policies. Spain and Greece are just two dramatic examples. In both countries, 
large popular movements and insurrections from 2011 onwards strove to alter the fundamental co-ordinates of neoliberal governance and even to transform the main economic and political institutions. But governments and institutions remained largely impervious to the demands for 'real democracy', economic fairness and the protection of social rights.

In a broader perspective, any effective politics for the expansions of the commons would need to engage state and market forces in order not only to relax the daily constraints they exert on social majorities deeply embedded in their networks of power but also to defend and recover public goods for the commons, also halting environmental degradation and climate change. Strategies of exit and prefiguration, whereby civic initiatives construct their own alternative institutions of social reproduction and self-government in the interstices or 'outside' dominant systems, can only be one part of the larger equation. For the great bulk and a vast range of resources, from energy grids to internet, transport, water, health, cultural heritage and educational infrastructures or large-scale means of production, it is either infeasible or unreasonable and environmentally disastrous to create other, parallel structures. The vexing challenge remains, thus, to place major social resources and infrastructures under collective control for the common benefit of society and our planet, reclaiming them from state bureaucracies, neoliberal governments and predatory private interests. Culture and cultural heritage stand out among such resources and infrastructures, particularly in urban settings. It is no accident, therefore, that they have become hubs of commoning activity, particularly in the Italian case, as we will see below.

In Spain, from 2014 onwards, several citizens' initiatives and political platforms were put together in order to gain a grip on institutional power on the city level. They all opted for hybrid schemes of action and structure in order to both uphold grassroots mobilization and to pursue centralized co-ordination, electoral politics and institutional intervention. Civic platforms set out to propel commoning and participatory self-governance in the city by contesting municipal elections and gaining local power (see Barcelona en Comú 2016). This process introduced in effect a certain political strategy of 'municipalism' which purports to expand the logics and practices of the commons on the scale of cities and is instantiated in diverse locations across Spain, from Barcelona to Madrid, Zaragoza, Valencia.

Their objective in building a coalition to win local elections was to advance a new, participatory model of local government, a system of transparent and accountable governance that would be under citizens' control. They wanted to initiate fair, redistributive and sustainable policies starting from the grassroots. Crucially, the proximity of local government to the citizens enables collective platforms which act as mediators to take social change from the streets to state institutions. Although the autonomy of municipal authorities was curtailed in the years of the crisis in Spain, the institutions of city government remain the closest to citizens and their demands. At the same time, they maintain varying 
degrees of control over important common goods, from land to transport, housing, the health system, education, energy and water, which they have come under increasing pressure to privatize or further commodify or subject to austerity cuts (Observatorio Metropolitano 2014: 106-109, 135-137). The city is, therefore, a central site of the struggle around the common goods.

In Italy, civic politics around the commons has walked along different, albeit parallel, pathways, in which complex relations have been woven between grassroots movements, citizens' groups, municipal authorities and progressive jurists, such as Ugo Mattei and Francesco Gregorio Arena. The 2011 national referendum against the privatization of water was a milestone in these processes, followed by the occupation of Teatro Vale in Rome, which was explicitly informed by a commons discourse. Since then, 'bene comuni' has become a buzzword of feel-good and 'alternative' politics in Italy (Kioupkiolis 2018). Discourse and political practice around the commons are pervasive in presentday Italy, and they are perceived by several political actors as a constructive response to the economic, social and political crisis. Commons-related activity has often focussed around specific issues, such as water and culture, and is anchored at the level of the municipality.

\section{The role of law and jurists is particularly prominent in commoning processes in the Italian context}

The quasi 'empty signifier' of bene comuni refers to different realities in the country, but it signals a shared commitment to denounce the concentration of power, to attend to local inequalities, and to pursue other ways of possessing and producing, which would transcend the market order imposed by the neoliberal model (Kioupkiolis 2018). Through the common goods, a dialogue has opened up with the militant academy. Law has furnished a potent tool for articulating an incisive criticism of the existing structures. Movement practices and legal mediation have become two fundamental pivots for critical reflection on the legitimacy and the quality of public management and private property in the light of the most urgent social needs and contradictions, reviving the profound meaning of substantial equality and introducing a grammar of inclusion. This is based on the relational and shared dimension of the use of resources that should be conducted in ecological and qualitatively responsible ways, governed by the principle of equal access.

Lawyers and municipalities catalysed the expansion of the commons in the Italian context. Municipal authorities have introduced pro-commons regulations on the city level, drawing on provisions of the Italian constitution. In effect, in Italy there are currently three main approaches to the use of law for the purposes of urban commons: the 'Labsus model', the approach worked out by Ugo Mattei and his associates, and 'civic use' as articulated in Naples by social movements and jurists. 
The 'Labsus model' is based on the Italian constitution and, crucially, on the principle of 'subsidiarity' which calls for citizen participation in the administration and collective works. This was introduced into the Italian constitution in 2001 (A.118), and stipulates that all state institutions, on all levels, must favour the autonomous initiatives of citizens, individuals or associations, in order to foster the general interest on the basis of subsidiarity. Citizens, as allies of the administration, in horizontal relations, should address together the various crises that face them - economic, climatic, of migration etc. Jurists directly drew on the constitution in producing a regulatory framework that bypasses national legislation by introducing municipal legislation on the basis of the constitution. The Labsus group was established in 2005 by professors of administrative law to further this project (Heteropolitics 2018a).

The ambiguous but dynamic process of pro-commons regulations was inaugurated in Bologna in 2014 and has attracted thousands of citizens who have submitted hundreds of projects for the collective management of urban goods and infrastructure. It was largely a top-down institutional initiative, advanced by lawyers (mainly the Labsus group) and taken up by left-leaning mayors who sought to fill in the gap left by the demise left wing party politics in Italy. However, it has subsequently been embraced by more than 150 cities in the country, including Turin and Parma. Through the regulations, the local administration intends to transform itself into a facilitator (enabler) rather than a supplier of goods and services. Under this scheme, the administration has the task of helping those who discern in a building, a run-down area, or a flowerbed, the potential for a collective project of care and recovery of the asset, simplifying and streamlining the procedures required in order to obtain the necessary authorizations to start the reuse (Heteropolitics 2018a).

The cornerstone of the Bologna regulatory framework is Article 5: the pacts of collaboration, i.e. the contracts made between groups of citizens and the municipality in order to serve bene comuni. The most diverse combinations of actors enter into these pacts, from scouts to citizens' associations to migrant groups (Heteropolitics 2018a). The political vision driving the Bologna regulations is a society of care, trust and sharing, which fills in the lack of ideas about the future. This lacuna has come about due to the demise of the grand ideologies of the past. The void generates fear, but this can be remedied through trust and sharing. The communities of the commons could become a new collective subject, appealing to 'normal people.'

Jurists have also contributed to the 'commoning' processes in various other ways. These include the so-called 'Commissione sui Beni Comuni' chaired by the jurist Stefano Rodotà, which initiated a process that culminated in the 2011 water referendum. In 2007, the committee was commissioned by the Ministry of Justice to draw up a law to amend the rules of the Italian civil code on public goods. The proposal presented by the Commissione at the end of their activity enriched the taxonomy of public and private goods with a new category; common goods. The common goods are described as resources with widespread 
ownership, which may belong to public bodies or private subjects. Therefore, beyond the proprietary title, common goods possess the concrete possibility of collective access, within the limits and according to the procedures established by law, and therefore their management must serve this possibility (Kioupkiolis 2018).

In 2011, members of the Rodotà Commission were among those that framed the referendum questions that were put to vote on the $12^{\text {th }}$ and the $13^{\text {th }}$ June that year. The great success of the consultation (in which the 'yes' prevailed by $57 \%$ of those entitled to vote) popularized and advanced the concept of common goods. This became the key signifier of many different disputes and transformed it into a political category, freeing it from the confines of the legal realm in which it originated. Movements for the defence of land against speculative use and for the preservation of historical and cultural heritage, trade unions and housing movements have included the common goods among their slogans, not only because it is politically fashionable to do so, but above all because the term highlighted the concentration of power and processes of exclusion. Moreover, through the common goods, a dialogue opened up with the militant academy, and law was considered a necessary tool for a rigorous critique of the existing structures. Movement practices and legal mediation became two fundamental components for questioning a crystallized proprietary equilibrium (Kioupkiolis 2018).

According to Ugo Mattei (Kioupkiolis 2018), common goods have thus had the strength of the empty signifier. They have offered, thanks to their flexible content, a negative unity to different struggles which have become equivalent in a post-ideological scheme, by way of participating in 'struggles' for the defence of the commons. Moreover, the commons have also implied the possibility of taking part in the management of different assets, or even the possibility of inventing new institutions or rethinking old mechanisms. So, in Naples, the administration of the public water company was set to include also users in the governance of the company, while the Teatro Valle in Rome planned to organize its management through a private law entity. However, the foundation charter was modified in order to increase shared decision-making, to spread power and to advance participation in the management of the foundation's assets (Kioupkiolis 2018).

\section{The commons as an alternative model of co-governing and co-creating cultural goods and the example of L'Asilo in Naples}

This civic and institutionally driven path to the expansion of the commons in Italy is risky and tortuous, as it may in effect devolve public financial and administrative responsibilities to citizens, substituting cheap and voluntary labour for public funding and administration. On the other hand, it outlines 
another model of preserving, reusing and revitalizing cultural heritage. Society is no longer confined to the role of the consumer of privately managed goods or the passive recipient of public management. Democratic communities re-appropriate cultural spaces and goods as active co-administrators and co-creators - from theatres and museums to abandoned historic buildings that host artistic activities - as active co-administrators and co-creators. They craft different figures of communal living and bonding, which are freer, more equal, participatory, self-governing, creative, open, diverse, solidary and caring. They make cultural goods and infrastructure a site of renewed collective life, participatory governance, cultural revitalization, new creation, and sociopolitical experimentation. Hence, they open up cultural goods and heritage to the common, turning them into common goods and an activity of a heterogeneous, inclusive community that involves ordinary people. The case of L'Asilo Filangieri will serve to illustrate these transformations.

As a key hub of urban commoning activity in Italy, Naples, has framed its own institutional scheme in favour of the commons. The municipality has promoted civic participation in the management of urban infrastructure, such as water, and the use ('uso civico') of public buildings by associations of artists; also in the emblematic ex-Asilo Filangieri, among others. This development was largely the outcome of a synergy between independent social movements and the singular populist persona of the mayor, Luigi de Magistris. The case of L'Asilo elucidates the different paths taken in Italy by social movements which seek to gain leverage on institutions in order to advance the commons and civic empowerment. In contrast to Spain, where social movements, activists and citizens came together in electoral municipal platforms with a view to becoming city administrators, in Italy they strive to make an impact on the formal political system through an intelligent, diverse and inventive use of the law. This charts a different avenue to gaining leverage on political institutions, which is worth considering and debating. Perhaps, it allows egalitarian social movements to uphold a higher degree of political independence and creative autonomy.

'L'Asilo', as it is called by participants, pursues further the process of commoning artistic activity, community and politics which was initiated by Teatro Valle in Rome in 2011, a landmark in the recent history of the commons in Italy. In a sense, l'Asilo takes up where Teatro Valle left off. L'Asilo was a convent located in the historic centre of Naples and established in the $16^{\text {th }}$ century. In 2008 it was restored in order to host a Universal Cultural Forum. This event was organized by a private association which was funded with public money. L'Asilo started with a symbolic occupation staged by a group of artists and cultural workers ('Balena') in March 2012, who protested against the public sponsorship of such events at time when artistic work was under-funded and neglected. Gradually, the assembly brought together 300-400 people who decided to stay in the building (Heteropolitics 2018b). 


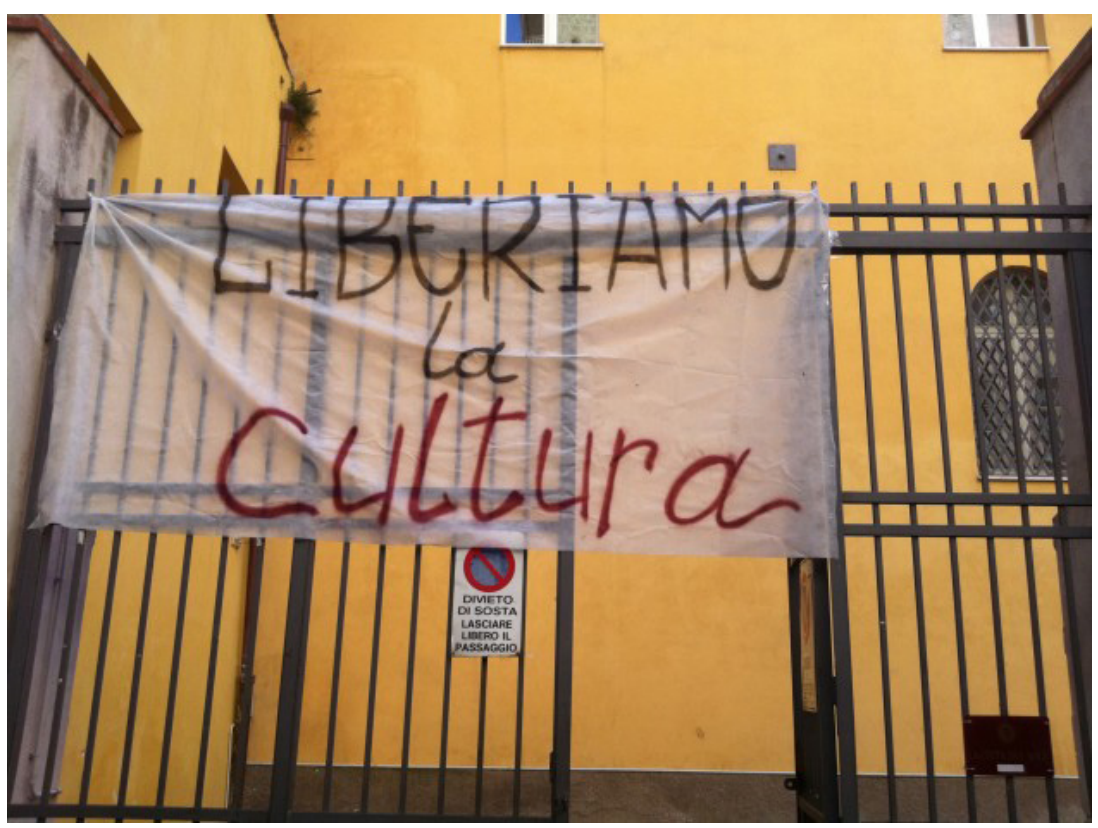

Figure 1: L'Asilo Filangieri: The first day of occupation (Source: Riccardo Siano).

This movement was part of a broader pro-commons political mobilization in Italy in 2011, which included the national campaign for the defence of water as a common good, the occupation of Teatro Valle in Rome and Macao in Milan. There was then a contagion of movements for the commons. In Naples, the city administration was already sponsoring the commons, having introduced the notion of culture as a common good in the City Statute (Heteropolitics 2018b).

The commons in 'L'Asilo' embodies a civic and cultural praxis which pivots around a) collaborative artistic creation and experimentation; b) egalitarian democratic self-management; c) self-legislation through the production of an internal regulation that was finally ratified by the municipality after a long struggle; d) the making of a different community and politics informed by openness, plurality, horizontality, non-violence and non-domination, consensus, collaboration, and experimentation; e) the negotiation of a different relationship with the municipality characterized by both collaboration, struggle, conditional municipal support and autonomous self-organization of the community in l'Asilo (see Heteropolitics 2018b).

More specifically, l'Asilo illustrates the 'uso civico' approach to the commoning processes of Italian cities, the relations of pro-commons social movements with municipalities and the attitude of city administrations towards the commons and civic groups. The lawyers who joined after the beginning of the occupation suggested a legal route, which would combine the legal provision 
of civic use, concerning originally natural resources and 'traditional' commons, with the Article 43 of the Constitution, which allowed for the takeover of a public service by the community of its workers in certain conditions. Finally, in December 2015, the municipality issued a new administrative act, co-authored by l' Asilo and based on a self-regulation statute wholly drawn up by l'Asilo. L'Asilo has subsequently extended these explorations and their collaborative work with the de Magistris administration to other seven spaces, totalling about 40.000 square meters of occupied real estate (Heteropolitics 2018b).

Through this regulation, the main idea of the community of l'Asilo was to 'hack' the law. They made a declaration of urban and collective civic use. The legal instrument worked out by l'Asilo can now also be used by others and it has been deployed for the recognition of eight more spaces, which are now drawing up their declarations of use. The idea of the recognition of a 'collective use' that has already started is powerful, and it is different from the 'constitution' of such a use only after the municipality decides. L'Asilo is thus an attempt to connect social movements with a juridical path. It involves an endeavour to hack the legal system in order to configure new institutions, using the law to change the system 'from within.' L'Asilo can offer an example, a precedent in legal terms, which introduces the idea of self-organization in new juridical institutions (Heteropolitics 2018b).

What is more, l'Asilo seeks to combine the 'civic use' of the commons with public property and support. It relies on public funding from the municipality for some of its functions (for the maintenance of the building and basic operational expenses, such as electricity; Micciarelli 2018). L'Asilo is not and does not desire to become, 'self-sustainable' on the market, in financial terms. This contrasts to some degree with other models of urban commons in Italy, whereby collectives and associations collaborate with municipalities and sign 'pacts' with the city administration on the condition that they become self-sustainable financially. The political predicament here is whether cultural activities should operate according to the logic of the private market or whether they should be sponsored by public funds and the redistribution of wealth. In a commonsbased society, a part of the wealth produced in the narrower economic sphere of material production could, or should, be redistributed to other activities, from education to health and culture, which are likewise productive or creative in a broader sense. Such activities contribute to the 'economic basis' by sustaining social reproduction but also by fostering the growth of knowledge, creativity, culture and ideas, which again feed into material production for social needs in a narrower sense.

Regarding the alternative politics of the commons and the alternative model of governing cultural heritage which are performed in l'Asilo, these are focused on the public assembly which makes the key decisions in the space. In l'Asilo, there is no collective, only a public assembly and different worktables which were established as the self-governance system of a heterogeneous community. Different people are involved in l'Asilo, both in terms of their profession 
(artisans, actors, cultural workers, researchers, unemployed and students) and in terms of political identity (from anarchists to greens, communists to social democrats and even non-political people). All of them work together on the understanding that they are not driven by a monolithic ideology and they do not vie for internal hegemony, but they resist the dominant legal in order to invent a new institution (Heteropolitics 2018b). To develop this common process of collaboration, they mobilize the law (the regulation), humour, and psychology. It is the commoning (activity in common) that forges the bond. Thereby, a diverse and open community comes into being (Heteropolitics 2018b).

L'Asilo represents an attempt to invent new institutions for the communal self-management of public infrastructure and cultural heritage, through which people in a building can regulate in concert the ways in which they can enter public spaces, use means of production, decide and co-decide as a deliberating subject. This practice contrasts with the hegemonic political model, in which only one or few subjects decide. To realize this other practice, they also draw on a certain interpretation of the Italian Constitution and a theoretical idea of fundamental rights (including the radical right of the freedom to create new democratic institutions). They propose a practice of direct administration in which people perform public functions, coordinating themselves with the public administration, where necessary, in order to demand services, rights and duties that they cannot always provide themselves. Starting from the management of buildings and cultural heritage, this model could extend to public services and beyond. Three core elements make up this political ideal: 1) the collective use of the means of production; 2) direct administration through an assembly which is open to everyone, but follows certain rules and excludes racism, fascism and gender violence; 3 ) the right to different uses spread among different experiments (Heteropolitics 2018b).

More broadly, l'Asilo combines long-term political reflection with an everyday attention to social relations within itself. The community does not always engage in actual politics. L'Asilo is, rather, an ongoing and fluid experimentation, by an ever-shifting community that is not animated by a precise vision for the future but undertakes an experimentation about which it is very conscious. Hence, l'Asilo is now developing a broad reflection on the assembly itself and its functions of information-sharing and decision-making. A principal focus of the assembly is its opening to newcomers. They seek, thus, to be conscious and clear about the workings of the assembly through systematic internal reflection and external projection (Heteropolitics 2018b).

In short, l'Asilo is a gate for all, and a galvanizing place, bringing together people from all around the world. Every process comes from people who have different points of view. To work for the common good, they need and they try to be open-minded and to trust each other. Hence, l'Asilo is not a place to reach a final answer but a means of dreaming about a different way of living in the future. A core political idea of l'Asilo lies in practicing different relations. Participants do not want to use more power over others and to compete. Rather, they want to share their different knowledge, without seeking any advantage 


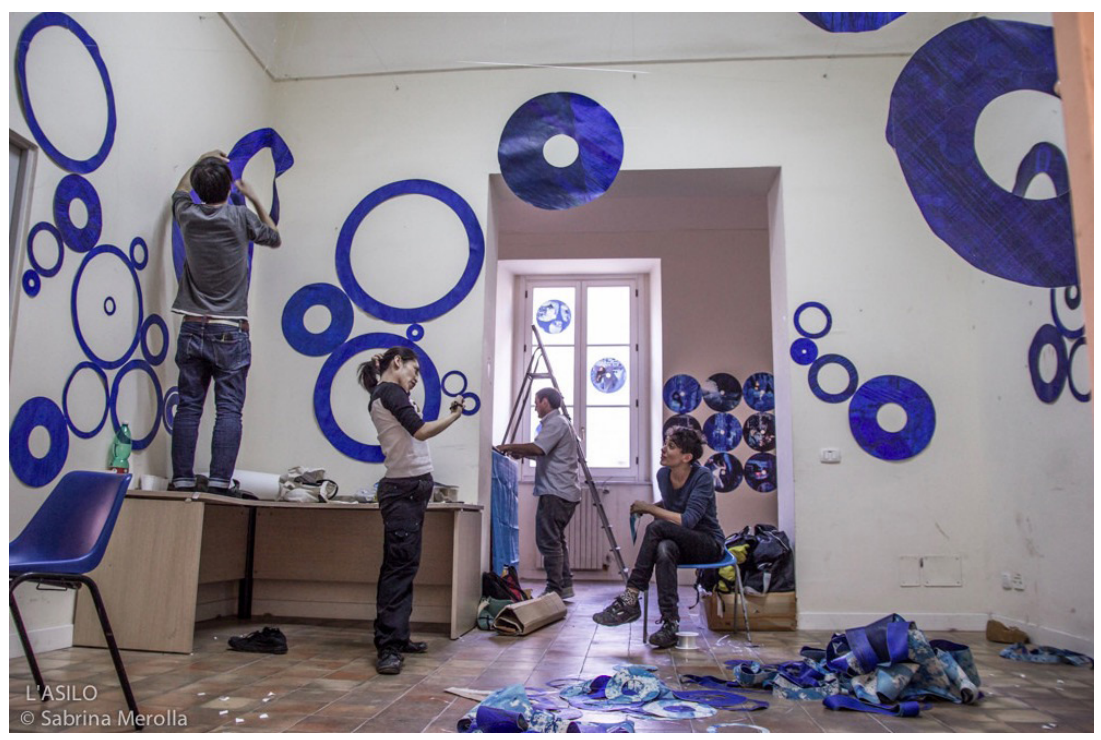

Figure 2: L’Asilo Filangieri (Source: Sabrina Merolla).

from the exchange. They offer help to others for free. This knowledge exchange occurs not only between two individuals, but the community as a whole. A person may conceive the project of an installation, which s/he shares with others in order to produce a common project. The will to share and do things in common referred to as 'interdependence'. For participants in l'Asilo, the future lies in this kind of community, in which one's freedom is more open to the freedom of others. Moreover, people in l'Asilo try out ideas in practice and they use them when they work. But everything is always changing in an unexpected way, as a never-ending river, and a process, not an institution. The whole point of l'Asilo is 'to let a seed become a tree' (Heteropolitics 2018b).

\section{The political creation of the commons}

In a time of fascist deviations, imperial neoliberalism and apparent impasse, the common(s) have gained salience as the nodal point of an emergent political imaginary and a growing constellation of forces. The commons uphold and renew what is best in the egalitarian traditions of modernity, from communism to socialism and anarchism: social self-government, collective property, equal freedom, solidarity, inclusion, open creativity, care for the environment. At the same time, they can resonate beyond the historical left and they are free of the darkest pages in the modern history of radical politics.

Since the turn of the century, multiple forms of democratic agency and mobilization have also sketched the rudiments of another counter-hegemonic strategy, which can assemble forces, attain cohesion, exercise leadership and make a 
universal address without succumbing to the logics of fusion, top-down direction and 'realist' power games. Grounded in prefiguration and in grassroots control, counter-hegemonic politics could guide the whole process of transformation from below and could effectively expand the political logic of the commons: horizontal participation, sharing, diversity, openness, sustainability and care. Such strategies of 'another politics' mix horizontalism and verticalism with a clear emphasis on the former, combining heterogeneous spatialities and temporalities. They are anchored in the here and now; this world, its urgent needs and its ordinary people. Yet they are also oriented towards new worlds of freedom, plurality, openness and equality, which pertain to the long term and require arduous processes of reflection, struggle and invention.

In contrast to the central stage of national politics, cities are a privileged site in which these alternative strategies for the commons could take hold, unfold, engage with dominant institutions and reshuffle the balance of power. On account of their proximity, municipal institutions are more easily accessible to direct civic influence and participation. At the scale of the city and urban neighbourhoods, ordinary citizens can also exert effective control over their representatives, if they craft proper forms of political organization through public assemblies and digital or other networks, enforcing transparency and accountability. Recent experience from the new 'municipalist politics' suggests the need to sustain new schemes of 'dual power' or 'disjunctive conjunction.' To build autonomous bases of collective power that will gain leverage on ruling institutions and alter hegemonic formations in politics, economy and society, people should construct alternative institutions of the commons, wherever this is meaningful, they should self-organize at the grassroots and multiply civic initiatives of social reconstruction and empowerment over existing social structures. But without losing their primary focus on autonomous self-activity, participants in these processes should also take part in, or forge ties with political platforms which can exert influence on institutions of government or even strive to directly control them in order to open them up to people's power, to democratize the management of public goods and to divert resources to the commons.

The cities remain an apposite site in which extensive direct participation of lay citizens in political decision-making can take place, and institutions of government can become directly accountable to the people. At the same time, and despite the growing fiscal and political constraints inflicted on them by central governments, international institutions and global markets, cities are hubs of economic, social, cultural and political activity. And their governments maintain a degree of control over urban resources, infrastructures and flows of capital. City-based politics can scale up to address national and international structures of power by federating and networking municipalities and movements to put strong pressure on higher scales, while maintaining a solid anchorage in extensive participation and political direction at the bottom in each locality. 
This is not simply an ideal projection. It is already occurring at an incipient stage, both in Europe and across the world. City-based politics along these lines promises to foster a progressive egalitarian populism for the common $\operatorname{good}(\mathrm{s})$ where traditional and new leftist parties have failed. Fundamental democratic change is, of course, premised on the active desire and engagement of large bodies of citizens. But in the presence of such a will and mobilization, city politics re-organized along the lines of disjunctive conjunctions between people and their representatives promises to aggregate, to channel and to amplify the power of the many against the entrenched rule of the few.

This alternative city politics can take place and flourish in a multiplicity of social spaces, practices and relations, combining distinctive activity and creativity with broader political processes and experiment. The case of l'Asilo in Naples illustrates these innovative potentials and the dynamic of the commons in the field of art, culture and cultural heritage. LAsilo mixes art, culture and politics in ways which are open, pragmatic, critical, free, democratic, creative, experimental and caring. The commons in l'Asilo thus break with the logics of top-down, bureaucratic government, profit-seeking capitalist entrepreneurship and cultural elitist administration. In their words: "The Ex Asilo Filangieri, former seat of the Forum of Cultures, is since 2 March 2012 a public space dedicated to artistic and cultural production and flourishing. This space is selfgoverned by a heterogeneous, mutable, solidary and open community, through practices of shared and participatory management, which are akin to civic use. In l'Asilo, the organization of space and the planning of activities take place in a public and horizontal way, through the assembly and roundtables which promote encounters, sharing and experimentation". ${ }^{92}$

Those who inhabit l'Asilo recognize themselves:

- in the repudiation of every form of fascism, racism, homophobia and sexism through active policies of inclusion and the affirmation of singularities;

- in the liberation of artistic expression and culture from the logic of profit and the market, as a manifestation of creativity, freedom and human personality, and as a fundamental contribution to the qualitative growth of society;

- in interdisciplinarity and the sharing of arts, sciences and knowledge, with a view to liberating labour by fostering a vision of cooperative and noncompetitive human relationships that follows the principle 'from each according to their own possibilities and capabilities, to each according to their needs and desires';

92 Self-presentation of l'Asilo, available at https://www.facebook.com/lasilo/. Last access 21 July 2018; translated from Italian into English by Maria Deligiannidou. 
- in the independence of cultural and artistic organization from interferences external to the practice of self-government;

- in interdependence, understood as the dependence of the community on the collaborative capacity of the individuals who recognize themselves in it;

- in the pursuit of consensus in decision-making, in order to build a common, 'co-divided' process of decision-making process through an inclusive and non-authoritarian method.

\section{Bibliography}

Badiou, A. (2012). The rebirth of history: Times of riots and uprisings. London, United Kingdom: Verso.

Barcelona En Comú. (2016). How to win back the city En Comú: Guide to building a citizen municipal platform. Retrieved May 3, 2017, from https://barcelon aencomu.cat/sites/default/files/win-the-city-guide.pdf.

Bauwens, M. (2005). The political economy of peer production. CTheory, Issue 1000 Days of Theory. Retrieved March 20, 2017, from http://www.ctheory .net/printer.aspx?id=499.

Bauwens, M. (2009). Marx, cognitive capitalism and the transition to the commons. Retrieved March 20, 2017, from http://dev.autonomedia.org /node/13285.

Bauwens, M. (2011). Should we worry about capitalist commons? Retrieved March 20, 2017, from https://blog.p2pfoundation.net/should-we-worry -about-capitalist-commons/2011/03/23.

Bauwens, M. \& Kostakis, V. (2014). From the communism of capital to capital for the commons: Towards an open co-operativism. tripleC, 12(1), 356-361. DOI: https://doi.org/10.31269/triplec.v12i1.561.

Bauwens, M., Kostakis, V. \& Pazaitis, A. (2019). Peer to Peer: The commons manifesto. London: Westminster University Press.

Benkler, Y. \& Nissenbaum, H. (2006). Commons-based peer production and virtue. The Journal of Political Philosophy, 14(4), 394-419.

Bollier, D. (2008). Viral spiral: How the commoners built a digital republic of their own. New York, NY: New Press.

Benkler, Y. (2006). The wealth of networks: How social production transforms markets and freedom. New Haven, CT: Yale University Press.

Caffentzis, G. (2013). In letters of blood and fire: Work, machines, and the crisis of capitalism. Oakland CA: PM Press.

Crouch, C. (2004). Post-Democracy. Cambridge, United Kingdom: Polity.

Dellenbaugh, M., Kip, M., Bieniok, M., Müller, A. K \& Schwegmann, M. (Eds.). (2015). Urban commons: Moving beyond state and market. Basel, Switzerland: Birkäuser Verlag GmbH.

Dixon, C. (2014). Another politics: Talking across today's transformative movements. Oakland, CA: University of California Press. 
Dyer-Witheford, N. (2010). The circulation of the common. Retrieved August 20, 2015, from http://www.globalproject.info/it/in_movimento/nick-dyer -witheford-the-circulation-of-the-common/4797.

Dyer-Witheford, N. (2015). Cyber-proletariat: Global labour in the digital vortex. London, United Kingdom: Pluto Press.

Harcourt, B. E. (2011, October 13). Occupy Wall Street's 'political disobedience'. The New York Times. Retrieved June 20, 2012, from https://opinionator.blogs .nytimes.com/2011/10/13/occupy-wall-streets-political-disobedience/.

Hardt, M. \& Negri, A. (2012). Declaration. Argo-Navis Author Services.

Heteropolitics. (2018a). Report on the fieldwork in Bologna, Italy, as conducted by the PI: Alter-politics and commons in Bologna, 4-10 June 2018. Retrieved June 21, 2019, from http://heteropolitics.net/index.php/ethnographic-mat erial/.

Heteropolitics. (2018b). 'To let a seed become a tree': Urban commons in Naples: Short report on the field visit by A. Kioupkiolis and interviews 30 November5 December 2018, with A. Vesco. Retrieved June 21, 2019, from http://hetero politics.net/wp-content/uploads/2019/01/Short-report-on-commons-in -Naples.pdf.

Hoare, Q. \& Nowell Smith, G. (Eds.). (1971). Selections from the Prison Notebooks of Antonio Gramsci. London, United Kingdom: Lawrence and Wishart.

Kioupkiolis, A. (2018, July 17). Audio from the 2nd day of the Torino workshop on law, the commons and politics in Italy, with Ugo Mattei, Alessandra Quarta and Rocco Albanese. Retrieved June 21, 2019, from http:// heteropolitics.net/index.php/2018/07/17/audio-from-the-2nd-day-of-the -torino-workshop-on-law-the-commons-and-politics-in-italy-with-ugo -mattei-alessandra-quarta-and-rocco-albanese/.

Laclau, E. (2000a). Structure, history and the political. In J. Butler, E. Laclau \& S. Žižek (Eds.), Contingency, hegemony, universality: Contemporary dialogues on the Left (pp. 182-212). London, United Kingdom: Verso.

Laclau, E. (2000b). Constructing universality. In J. Butler, E. Laclau \& S. Žižek (Eds.), Contingency, hegemony, universality: Contemporary dialogues on the Left (pp. 281-307). London, United Kingdom: Verso.

Laclau, E. (2005). On populist reason. London, United Kingdom: Verso.

Laclau, E. \& Mouffe, C. (1985). Hegemony and socialist strategy: Towards a radical democratic politics. London, United Kingdom: Verso.

Nez, H. (2013). Among militants and deliberative laboratories: The Indignados. In B. Tejerina \& I. Perugorria (Eds.), From social to political: New forms of mobilization and democratization. Conference Proceedings. 9-10 February 2012 (pp. 123-139). Retrieved November 20, 2019, from https://addi.ehu.es/bitstream/handle/10810/15294/UWLGSO5952.pdf? sequence $=1$ \&isAllowed $=\mathrm{y}$.

Nunes, R. (2014). Organisation of the organisationless: Collective action after networks. Berlin, Germany: Post-Media Lab/Mute Books. 
Observatorio Metropolitano. (2014). La apuesta municipalista: La democracia empieza por lo cercano. Madrid, Spain: Traficantes de Sueños.

Ostrom, E. (1990). Governing the commons: The evolution of institutions for collective action. Cambridge, United Kingdom: Cambridge University Press. Standing, G. (2011). The precariat: The new dangerous class. London, United Kingdom: Bloomsbury Academic.

Tormey, S. (2015). The end of representative politics. Cambridge, United Kingdom: Polity Press.

Walljasper, J. (2010). All that we share: A field guide to the commons. New York, NY: The New Press. 